\title{
No Clear Objective: The Simons Report on Foreign Aid
}

\author{
Peter Warr
}

\begin{abstract}
USTRALIA'S foreign aid programme currently costs taxpayers around $\$ 1.5$ $A$ billion a year, equivalent to about $\$ 100$ for each Australian. The recently 1 released Simons Report, titled One Clear Objective: Poverty Reduction through Sustainable Development (Committee of Review on Australia's Foreign Aid, 1997), reviews the aid programme. It is a welcome and long overdue contribution to the formulation of Australia's policy in this important area. The Report contains much that is sensible and constructive and its recommendations are wide-ranging. They attempt to reformulate the principles guiding Australia's foreign aid. One of the Report's stated objectives is to stimulate a vigorous debate. In that it has succeeded and, in the spirit of that objective, I offer this contribution to the debate.
\end{abstract}

\section{The Objectives of Aid}

The predecessor to the Simons Report was the 1984 Jackson Report, which articulated three objectives for aid: humanitarian, diplomatic and commercial (Committee to Review the Australian Overseas Aid Program, 1984). The Simons Report recommends substituting the one objective of poverty reduction referred to in its title. I have three problems with this proposed change.

The 'one objective' is not clear. The Report does not define 'poverty reduction'. Some passages imply that it means alleviation of absolute economic hardship, while others suggest that it means reduction of relative inequality, sometimes also called 'relative poverty'. For example, the Report cites the World Bank estimate that between $800 \mathrm{~m}$ and 1.3 billion people subsist on less than US\$1 a day, and then goes on to say that 'Massive inequalities are self reinforcing and destabilising' (p. 55). These two interpretations of 'poverty' are very different. Absolute poverty incidence and relative inequality are not the same thing; they do not necessarily move even in the same direction over time; and their economic determinants are quite different.

An illustration of the difference between these two concepts is provided by the recent experience of Thailand (see Warr, 1994). The Thai government's household survey data reveal that over the two decades since the mid-1970s relative inequality in Thailand increased, while absolute poverty fell. The share of total in-

Peter Warr is the John Crawford Professor of Agricultural Economics in the Research School of Pacific and Asian Studies, The Australian National University. 
come received by the poorest one fifth of the Thai population fell from 6.1 to 3.8 per cent over the period 1975 to 1994 . But this does not mean that the poor were worse off in absolute terms, because total Thai income per person more than doubled in real terms over the same period. The poorest one-fifth of the population (quintile) gained in absolute real income by around 50 per cent, even though the richest quintile gained proportionately three times as much, by around 150 per cent, again at constant prices. Over the same period, the incidence of absolute poverty, as measured by the proportion of the population whose incomes fell below a 'poverty threshold' level of income held fixed in real purchasing power over time, fell from 30 per cent of the population in 1975 to just under 10 per cent in 1994 (Bangkok Post, 1996).

Hardly anyone would say that the form of development Thailand experienced was ideal, but did it reduce poverty or increase it? The answer depends on what we mean by 'poverty', but the Simons Report is ambiguous about this central matter. If a foreign aid programme, or any other tool of policy, were to be built around the pursuit of a single objective, that objective would need to be made much clearer than it is in this Report.

In confusing absolute poverty with relative inequality, the Simons Report is not alone. The Australian Parliament's Joint Standing Committee on Foreign Affairs, Defence and Trade argued in 1996 that the government's newly established Committee of Review into Australia's aid programme (the Simons inquiry) should:

consider further the issue of the relationship between economic growth and the alleviation of poverty with specific reference to the dangers of polarisation of the rich and the poor. (Parliament of Australia, 1996:11)

This recommendation confuses the relationship between economic growth and relative inequality ('the polarisation of the rich and the poor') with the relationship between economic growth and the incidence of absolute economic hardship ("the alleviation of poverty'). They are not the same, and it is disappointing that the Simons Report confuses them again.

The Report says that:

Leading development organisations such as the World Bank and the United Nations Development Programme now agree that in addition to promoting growth in a broad sense, aid interventions need to be more carefully targeted to promote patterns of growth which maximise the impact on poverty. (p. 77)

For this to become more than rhetoric, we must begin by saying what we mean by 'poverty'; but that is only a beginning. Very little is currently known about the manner in which absolute poverty, relative inequality or any other specific conception of 'poverty' is affected by different forms of aid intervention. This is presumably why 
most of what the Simons Report says about the way poverty is affected by different forms of aid, and different patterns of development, consists largely of platitudes.

The Report equally fails to define 'sustainable development'. In the development literature, the concept of sustainable development has been defined in so many contradictory ways that it has virtually no value as a tool of communication. As my colleague, Professor Ron Duncan, puts it, no one is against 'sustainable development' because it is a tautology: if development were not sustainable, it wouldn't be 'development'. But beyond that, no one seems to know what it means.

Why only one objective? Aid is a component of Australia's overall foreign policy. That policy has multiple objectives, more or less as described by the Jackson Report in 1984 (see p. 362 above). Ideally, each component of foreign policy should reflect those objectives. It is inefficient for any one component of foreign policy to be confined to the pursuit of only a single goal. From the point of view of the Australian taxpayer, it would seem reasonable to say that: (i) if foreign aid is to be constrained to the pursuit of only one objective it will then be a less efficient instrument for the pursuit of Australia's overall foreign policy objectives; and (ii) in that case, there should presumably be a lot less of it. That is, by unnecessarily restricting the objectives served by foreign aid, the recommendations of the Report threaten to undermine the constituency for it, and this is potentially self-defeating for the pursuit of the very goals the Report wishes to promote.

The Report is self-contradictory. Having insisted that poverty reduction through sustainable development should be the sole objective of Australia's aid, the Report then says this aid should be concentrated in the Asia-Pacific region. Why? The objective of poverty reduction at a global level might well be best served by concentrating all of Australia's assistance on, say, Somalia. The fact that almost no one would accept that extreme outcome, apparently including the Simons Committee members, reveals that 'poverty reduction' is not accepted as the sole function of foreign aid. It is only by appealing to objectives for aid other than poverty reduction, including Australia's diplomatic and trade policy goals, that the report's recommendations on the geographic focus of aid could be justified. But the central conceptual thrust of the report is the rejection of these objectives.

In its official response to the Simons Report, the Australian Agency for International Development (AusAID) accepted 'in principle' the recommendation that 'poverty reduction' should be the sole objective of Australia's aid, but modified this objective to read:

To advance Australia's national interest by assisting developing countries to reduce poverty and achieve sustainable development. (AusAID, 1997:16)

The role of the words 'advance Australia's national interest' becomes somewhat clearer from AusAID's response to the Simons recommendation that Australia's aid should be focused more tightly on the Asia-Pacific. AusAID accepts this in 
principle' as well, but notes that 95 per cent of Australia's aid is already focused on 22 Asia-Pacific countries. It adds that

The Government will consider options for further tightening this focus but considers opportunities are limited taking into account Australia's interests. (AusAID, 1997:8)

What interests could these be but the diplomatic and trade objectives that the $\mathrm{Si}$ mons Report recommends be disregarded?

\section{The Fungibility of Aid}

Like the Jackson Report before it, the Simons Report puts too much stress on the appropriate composition of aid. It overlooks the fact that aid is fungible.

Aid virtually always provides things that are substitutes, perfect or imperfect, for things the government of the recipient country is already providing through its own resources. When aid provides, say, more hospitals, the recipient country's government quite rightly takes that aid into account in determining the subsequent allocation of its own budget. It will reduce the expenditure on hospitals that it would otherwise have made, and spend more on, say, schools and defence equipment. The net outcome of the aid is that citizens of the recipient country end up with more hospitals than they would have had otherwise, but not as much more as the composition of the aid itself may suggest. They also end up with more schools and defence equipment. If the aid had consisted entirely of schools or defence equipment, the net outcome would have been approximately the same. When the aid provides things that are only imperfect substitutes for the government's own expenditures, this argument is weakened, but only slightly.

It follows that aid donors are deluding themselves if they believe that the composition of their aid determines its net effect on the goods and services finally delivered to citizens of the recipient country. The efforts of donors in that respect are largely undone by the adjustment of the recipient government's own budgetary allocations, in the light of its own objectives. The net effect of aid therefore depends primarily on just two factors: the volume of aid and the preferences of the recipient government. The final impact of the aid is therefore roughly the same as it would be if the recipient country were given money to spend as it pleased.

To the extent that we are concerned about the impact that aid has on the people of the recipient country, there are just two questions to ask. Do we want to give aid to a particular country, taking account of the policies of its government, and if so, how much? The aid might as well be given in money, but if we are required to donate in kind then the sole question to ask about the composition of that aid is: what form(s) of aid can we deliver most efficiently? 


\section{References}

Australian Agency for International Development (AusAID) (1997), Better Aid for a Better Future, Seventh Annual Report to Parliament on Australia's Development Cooperation Program and the Government's Response to the Committee of Review of Australia's Overseas Aid Program, Canberra (November).

Bangkok Post (1996), Year-end Economic Review, Bangkok (December): 22.

Committee of Review of Australia's Foreign Aid (1997), One Clear Objective: Poverty Reduction Through Sustainable Development, Australian Government Publishing Service, Canberra (The Simons Report).

Committee to Review the Australian Overseas Aid Program (1984), Report, Australian Government Publishing Service, Canberra (The Jackson Report).

Parliament of Australia, Joint Standing Committee on Foreign Affairs, Defence and Trade (1996), The Australian Aid Program, Report on Proceedings of a Seminar, Canberra (September).

Warr, P. (1994), 'Myths About Dragons: The Case of Thailand', Agenda 1: 215-27. 